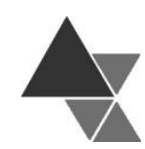

\title{
Amount of salt (sodium chloride) per capita used in a Public Hospital Food Service in Natal, RN, Brazil
}

\author{
Bruno Jonatan de Sousa ${ }^{1 *}$, Paula Angela Bessa Freitas de Oliva ${ }^{2}$, Thaís Araújo de Medeiros \\ Borges $^{3}$, Valtêmia Porpino Gomes Costa ${ }^{4}$ e Carla Cristina Monteiro ${ }^{5}$
}

During 31 days, this study determined and evaluated the amount of salt (sodium chloride) per capita used in the preparation of the lunch meals in a public hospital food service in the City of Natal, RN, Brazil. The quantification of the salt was done through the weighing of the salt container in the beginning and at the end of lunch preparation. After that, the total amount found on each day was divided by the number of meals (750), and then the per capita amounts were compared to the maximum intake recomentation $(5 \mathrm{~g} /$ day), and the maximum amount of salt estimated to be used for preparing lunch $(2.5 \mathrm{~g} /$ day $)$ in the food service studied, considering that this meal is planned to provide diners $50 \%$ of their caloric needs, even though the amount of salt used in the preparation of a meal does not necessarily represents the salt ingested, and plate waste should be considered as a modifying factor to salt intake. The results showed the per capita amounts of salt used for cooking lunch varied from $1.33 \mathrm{~g}$ to 5.87 $\mathrm{g}$, and the average for the 31 days was $3.11 \mathrm{~g}$. Only 14 days (45\%) were under the limit line established for lunch. The lowest and highest results could be associated to cooking techniques and ingredients required in the menu. The findings of this study are important since they provide support to the implantation of a control system for the distribution of salt from the storeroom to the kitchen, as well as data to elaborate guiding material to food handlers, and also campaign material that can be used to sensitize both the food service team and dinners (employees, patients and patient companions) about the use and consumption of salt, helping to decrease the health risks associated to a high-sodium diet.

Keywords: Sodium Chloride; Per capita; Lunch; Hospital food service.

\section{Teor per capita de sal (cloreto de sódio) utilizado em Unidade de Alimentação e Nutrição de um Hospital Público de Natal-RN, Brasil}

Este estudo determinou e avaliou, por 31 dias, o teor de sal (cloreto de sódio) per capita utilizado para a preparação do almoço em Unidade de Alimentação e Nutrição (UAN) de um hospital público da cidade de Natal, RN. A quantificação do sal foi realizada por meio da pesagem do recipiente central do sal da cozinha antes e depois da preparação da refeição. Em sequência, a quantidade total encontrada para cada um dos dias foi dividida pelo

* To whom correspondence should be sent.

${ }^{1}$ Food Science and Technology Specialist - Instituto Federal de Educ., Ciência e Tecnol. do RN (IFRN). Bachelor's in Nutrition - Centro Universitário do Rio Grande do Norte (UNI-RN). Nutrition Assessor at UNI-RN. 2000 Prefeita Eliane Barros, Natal, RN, 59014-545. E-mail: brunonutri@hotmail.com. ID ORCID: https://orcid.org/0000-0001-5367$236 \mathrm{X}$.

2 Bachelor's in Nutrition - Universidade Federal do Rio Grande do Norte (UFRN). Dietitian at Monsenhor Walfredo Gurgel Hospital. E-mail: paulaabfo@hotmail.com.

${ }^{3}$ Clinical Nutrition Specialist - Universidade Gama Filho. Bachelor's in Nutrition (UNI-RN). Dietitian at Monsenhor Walfredo Gurgel Hospital. E-mail: thaisara@terra.com.br. CV: http://lattes.cnpq.br/0505521816285622

${ }^{4}$ Masters in Biochemistry (UFRN). Bachelor's in Nutrition (UFRN). Dietitian at Maternidade Escola Januário Cicco (MEJC/UFRN). E-mail: valporpino@gmail.com.br. CV: http://lattes.cnpq.br/1584077800127316

${ }^{5}$ Clinical Nutrition Specialist (UNI-RN). Bachelor's in Nutrition (UNI-RN). E-mail: carlamnutri@gmail.com. CV: http://lattes.cnpq.br/8826128847401609. 
número de refeições (750), e então os valores per capita foram comparados ao limite máximo de ingestão recomendada $(5 \mathrm{~g} / \mathrm{dia})$, e à quantidade máxima de sal estimada a ser usada no preparo do almoço $(2,5 \mathrm{~g} / \mathrm{dia})$ no serviço de alimentação estudado, considerando que esta refeição é planejada para prover $50 \%$ das necessidades calóricas dos comensais, mesmo que a quantidade de sal utilizada no preparo de uma refeição não necessariamente represente o volume de sal ingerido, e que o índice de resto ingestão deva ser tido como fator modificante da ingestão de sal. Os resultados apresentaram valores per capita que variaram de 1,33 g a 5,87 g, e a média dos 31 dias foi de 3,11 g. Os dados mantiveram-se abaixo da linha estabelecida para o almoço em apenas 14 dias (45\%). Os valores (per capita) mais altos e mais baixos puderam ser associados às técnicas de cocção e ingredientes requeridas no cardápio. Os achados deste estudo são importantes uma vez que dão suporte para a implantação de um sistema de controle de liberação de sal a partir das despensas para a cozinha, assim como dados para a elaboração de material de referência para os manipuladores de alimentos, assim como material de campanha que possa ser utilizado para a sensibilização da equipe de produção de alimentos e comensais sobre o uso e o consumo de sal, e assim diminuir os riscos à saúde associados a uma dieta hipersódica.

Palavras-chave: Cloreto de Sódio; Per capita; Almoço; Serviço de nutrição hospitalar.

Submetido em: 20/09/2019

Aceito em: 24/02/2021

\section{INTRODUCTION AND OBJECTIVES}

The World Health Organization (WHO) has as a goal to decrease the number of deaths and diseases in the world. The organization highlights the need to reduce the risk factors to Noncommunicable Diseases (NCDs), also known as chronic diseases, through preventing actions. One of WHO's recommendations is that the population should limit the ingestion of salt (sodium) from all sources and ensure that salt is iodized ${ }^{[1]}$.

Sodium chloride $(\mathrm{NaCl})$ is the chemical name for table salt. The words salt and sodium are often used synonymously, although on a weight basis, salt comprises $40 \%$ sodium and $60 \%$ chloride ${ }^{[2]}$.

As a food ingredient, sodium has multiple uses, such as for curing meat, baking, thickening, retaining moisture, enhancing flavor (including the flavor of other ingredients), and as a preservative. Some common food additives - like monosodium glutamate, sodium bicarbonate (baking soda), sodium nitrite, and sodium benzoate - also contain sodium and contribute (in lesser amounts) to the total amount of "sodium" listed on the Nutrition Facts label[3].

WHO strongly recommends a reduction in the consumption of sodium to less than $2 \mathrm{~g} /$ day in adults ( $\geq 16$ years of age), which represents $5 \mathrm{~g} /$ day of salt, or a level teaspoon. For children and adolescents (2-15 years old), the intake of $2 \mathrm{~g} /$ day of sodium should be adjusted downward based on their energy requirements relative to those of adults, due to the positive association between energy requirements and sodium intake ${ }^{[4]}$.

\section{Food sources of sodium and salt intake}

The main source of sodium in our diet is salt, although it can come from sodium glutamate, used as a condiment in many parts of the world[2,5]. Sodium is found not only in table salt, but also naturally in a variety of foods, including milk, cream, eggs, meat and shellfish. It is also found in much higher amounts in processed foods, such as breads, crackers, processed meats like bacon and snack foods such as pretzels, cheese puffs and popcorn, as well as in condiments such as soy sauce, fish sauce, and bouillon or stock cubes[6].

Humans need very little salt for normal body functions. Most people consume too much salt - an average 9-12 grams per day, or around twice the recommended maximum level of intake ${ }^{[2,5,7]}$.

In Brazil, the average per capita estimated sodium intake, based on population food acquisition data, did not vary from 2002-2003 to 2008-2009 and reached around 4,700 $\mathrm{mg}$ of sodium or $12 \mathrm{~g}$ of salt per day. In both periods, most of the sodium was derived from kitchen salt or saltbased condiments and sodium 
intake from processed foods increased with household purchasing power $(9.7 \%$ of total sodium intake in the lower quintile of the per capita income distribution and $25.0 \%$ in the upper quintile $)^{[8,9,10]}$.

This means the ingestion of salt by the Brazilian population should be reduced by half to decrease the risk for cardiovascular diseases, such as coronary artery disease and high blood pressure[11].

The prevalence of diagnosed hypertension in Brazilian adults increased by over $14 \%$, from $22.5 \%$ to $25.7 \%$ over a ten-year period (2006 to 2016) according to the Vigitel Brazil 2016, which is a telephone survey on the surveillance of risk and protective factors for chronic diseases ${ }^{[12]}$. In 2020, the report of the same survey presented that in the 26 capitals of Brazil and in the Federal District the frequency of medically diagnosed hipertention was $24 \%$, being higher among women $(27.3 \%)$ than among men $(21,2 \%)$. The prevalence was higher for both women and men the older they were, and lower among those with an education levelhigher[23].

Although Brazilians ingest more salt than recommended [8,20,21], only $14 \%$ of the adults considered their consumption as high and over $80 \%$ of the population perceived it as adequate or low, in the 2013 National Health Survey that questioned about their self-perception of salt/sodium consumption ${ }^{[13]}$.

\section{Recommendations and health effect of high sodium intake}

Salt intake of less than 5 grams per day for adults helps to reduce blood pressure and risk of cardiovascular disease, stroke and coronary heart attack. The principal benefit of lowering salt intake is a corresponding reduction in high blood pressure ${ }^{[5]}$.

WHO Member States have agreed to reduce the global population's intake of salt by a relative 30\% by $2025^{[5]}$. Nilson et al. ${ }^{[14]}$ believe to be likely that gradual reductions in sodium content, due to the voluntary approach taken to setting sodium reduction targets in Brazil, allow food industries to develop the alternatives to reduce sodium more significantly and for consumers to adapt to foods with less sodium.

The $\mathrm{WHO}^{[5]}$ has listed key facts on the impact of high sodium consumption on health:
- An estimated 2.5 million deaths could be prevented each year if global salt consumption were reduced to the recommended level.

- High sodium consumption $(>2$ grams/day, equivalent to $5 \mathrm{~g}$ salt/day) and insufficient potassium intake (less than 3.5 grams/day) contribute to high blood pressure and increase the risk of heart disease and stroke.

- Reducing salt intake has been identified as one of the most cost-effective measures countries can take to improve population health outcomes. Key salt reduction measures will generate an extra year of healthy life for a cost that falls below the average annual income or gross domestic product per person.

\section{Objectives of the research}

Being the excessive ingestion of sodium a public health issue,aggravated by the changes in the frequency of eating meals prepared outside the house, this study aimed to determine and evaluate, for 31 days, the amount of salt (sodium chloride) per capita used in the preparation of lunch in a public hospital food service in the City of Natal, RN, Brazil, for employees, patients and patient companions whose meals were classified as regular meals (diets which require no nutrient or consistency changes for dietary therapy purposes).

\section{METHOD}

\section{Research site}

This research was conducted in the food service of a public hospital in the City of Natal, in the State of Rio Grande do Norte, Brazil. The hospital produces approximately 3,000 (three thousand) meals per day, of which 2,300 are produced to patients and patient companions, and the remaining 700 meals are served to the hospital's employees.

Sixty-six employees form the Food Service Team: 5 Registered Dietitian Nutritionists, 4 Nutrition Technicians, 15 Kitchen Assistants, 6 General Chefs, 2 Storeroom Assistants, 4 Cold 
Storeroom Assistants, 26 Assistants for Food Serving, 4 General Service Assistants.

\section{Research period, data collection, and salt quantification}

In this study, the lunch meal was the one chosen for data collection due to being one of the main meals served and also for being the one with a time window for preparation that would allow a better data control. The hospital produces approximately 750 lunch meals classified as 'regular', which are the object of this study.

It was observed that all the salt used in the preparation of the regular meals was taken from a central container and because of that, the quantification of the salt used to prepare lunch meals was done daily through the weighing of the salt container in the beginning and in the end of lunch preparation.

To improve data control, before the data collection, the central salt container was labeled "USE ONLY FOR LUNCH", since it is common for the chefs and kitchen assistants to start seasoning and preparing dishes for other meals, such as afternoon snack and dinner, prior to finishing lunch. A second salt container was placed in the kitchen with the sign "DO NOT USE FOR LUNCH".

The salt in the container was replaced every morning, before any cooking, guaranteeing the amount of salt would not be insufficient during lunch preparation, which would demand a second weighing.

In a meeting, chefs and kitchen assistants were informed about the two containers, one of which being the one that they were to collect salt from to prepare lunch dishes. They were also informed to use the regular amount of salt they usually used for preparing the lunch meals.

The data collection was conducted during the 31 days of March 2013. All the weighting procedures were conducted using a Urano US 15/5 POP-S scale, which had a 5 grams accuracy and carried an INMETRO Verification Certificate.

\section{Determining and evaluating the amount of salt per capita}

Knowing that a volume of food equivalent to an average of 750 lunch meals (classified as 'regular') were produced daily, and having the amount of salt used for preparingthose meals in each of the 31 days of this study, it was possible to find the amount of salt per capita.

Although the amount of salt used in the preparation of a meal does not necessarily represents the salt ingested, to evaluate the per capita amounts found was taken into consideration that the lunch meal of the food service here studied aims to reach up to $50 \%$ of the daily nutrient needs of the diners. Therefore, if the limit for salt intake, according to the WHO[4] is 5 grams/person/day, for lunch, the amount of salt should not exceed $2.5 \mathrm{~g}$. Besides being compared to the limits, the per capita amounts found were also associated with some of the dishes prepared.

In this study neither the salt content of ingredients nor the salt added by dinners during the meals were analysed.

The software Microsoft Excel 2013 was used for the analysis and display of the results of this study through descriptive statistics.

\section{RESULTS AND DISCUSSION}

In the Figure 1 are presented the results of the salt per capita amounts found on the 31 days. In the graph, the amounts found are compared to the daily limit for salt intake[ ${ }^{4]}$, and the estimated limit of salt for lunch $(2.5 \mathrm{~g})$.

Data showed that an average of $2.34 \mathrm{~kg}$ of table salt was used for preparing the lunch meal during the period of this study.

A large variation in the daily salt per capita amounts was observed. The lowest per capita was 1.33 $\mathrm{g}$ (day 13) and the highest amount, $5.87 \mathrm{~g}$ (day 6).

Out of the 31 days, only the per capita amounts found for 14 days (45\%) were under the limit line established for lunch, while for the other 17 days $(55 \%)$ values above the limit were observed. The results for three days $(6,21$, and 25$)$ exceeded the daily limit of $5 \mathrm{~g}$. 
The average per capita determined for the 31 days was $3.11 \mathrm{~g}$, which is $24 \%$ above the limit line for lunch, and considering salt to be $40 \%$ sodium, this amount represents 1,244 $\mathrm{mg}$ of sodium. The WHO[5] recommends that the daily intake of sodium should not exceed 2,000 $\mathrm{mg}$ (equivalent to $5 \mathrm{~g}$ salt/day).

Figure 1: Amount of salt per capita used for lunch

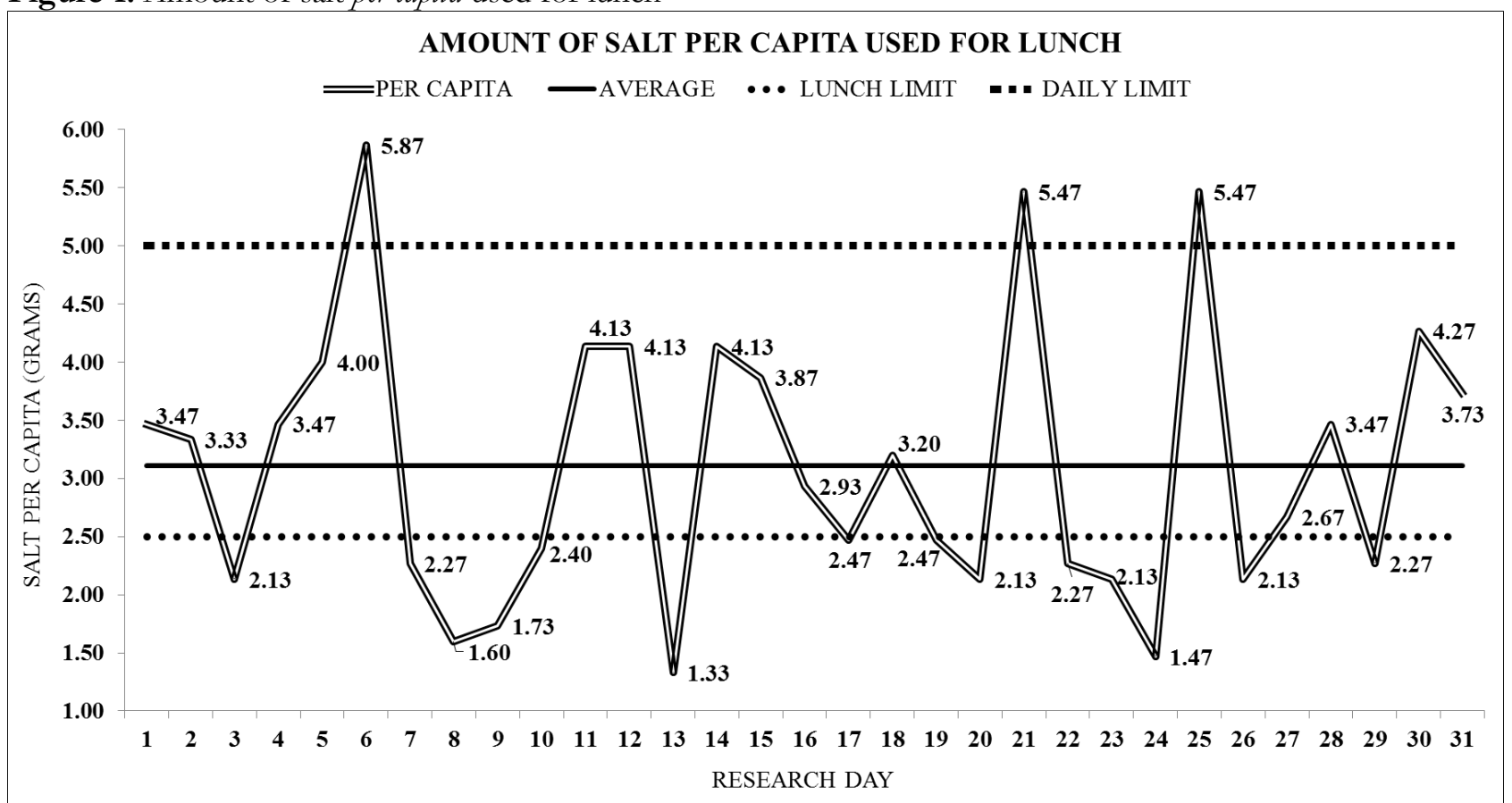

Source: Created by the authors. Natal, RN, Brazil (2019).

In their study to evaluate the quantity of sodium in the menu of a hospital food service, Borges and Conde ${ }^{[15]}$ also found results above the maximum limit recommended, as well as Ottoni and Spinelli ${ }^{[16]}$, whose study had as an average result $1,099.5 \mathrm{mg}$ of sodium per capita in the lunch of a school food service.

During three days, Bertoncello and Cintra ${ }^{[17]}$ quantified the amount of salt in the lunch meal of a food service in Brazil that serves 850 employees. They found amounts of salt per capita of $6.83 \mathrm{~g}, 5.07 \mathrm{~g}$ and $4.89 \mathrm{~g}$, in the first, second and third days respectively.

In Klein and Silva's[18] 10-day study to determine sodium consumption in a food service in Brazil before and during a campaign, they evaluated the sum of sodium in both lunch and dinner, and found an average of 3,120.00 $\mathrm{mg}$ of sodium (7.8 $\mathrm{g}$ of salt) on the week before the campaign, and 2,560.00 $\mathrm{mg}$ ( $6.4 \mathrm{~g}$ of salt) during the one-week long campaign. The authors ${ }^{[18]}$ evaluated the amount of sodium in the meals as inadequate and reinforced the relevance of strategies to promote the decrease of sodium intake.

Capalonga ${ }^{[19]}$ chose to evaluate the sodium content of 19 lunch menus for employees of a hospital food service in Brazil that produces on an average 1350 lunch meals. The author ${ }^{[19]}$ found an average per capita amount of $4.97 \mathrm{~g}$, being the meats the food items observed to contain the highest sodium contents.

The amount of salt used to prepare food depends on several factors and is directly connected to the dishes being prepared, and how the measurement of the salt happens. Facing that, besides the comparison to the intake recommendations, the results were correlated to the menu produced on the 31 days of this study.

On the days that presented the highest per capita amounts (5.87, 5.47 and 5.47), surpassing by more than $100 \%$ the maximum limit, the results could 
be explained by menus that contained spaghetti as a side. A considerably large amount of salt was added to the water used for the boiling of the spaghetti, which is discarded after cooking, and carries most of the salt used, being only a part of the saltincorporated to these dishes. Therefore, even though the daily limit was exceeded during these three days, it is not possible to certainly affirm that the offer of salt was higher than the recommendations.

Vegetable salads containing boiled diced vegetables such as potatoes, carrots, pumpkin, and chayote (mirliton squash) also go through the same process as spaghetti does, adding salt to the water for boiling, but discarding it afterwards.

On the other hand, the four days in which the lowest salt per capita amounts $(1.60,1.73,1.33$, and 1.47) were under the maximum limit could be explained by the presence of ingredients that contained high amount of salt, for instance, in the 8th day, the main dish was Feijoada, which is a typical dish in Brazil - a bean stew containing ingredients like dry meat (dehydrated by the use of salt), sausage, and jerked beef. Since the ingredients provide the necessary salt, the use of salt on those days was lower. It is important to highlight that on those days, even though less salt was used from the central container, the meals did not present a lower sodium content.

Roasted meats were part of the menu on the majority of the days that presented results between 2.5 $\mathrm{g}$ and $5 \mathrm{~g}$ of salt per day. No menu pattern was identified on days that presented per capita amounts of salt close to the reference $(2.5 \mathrm{~g})$.

The sodium content of a meal is the sum of the sodium in the ingredients and salt added during preparation. The sodium intake by dinners during a meal, on the other hand, should take into consideration the amount of food effectively eaten, considering the plate waste. Thus, this study did not evaluate the ingestion of sodium by dinners.

Souza et al.[22] analyzed the amount of sodium offered to hospitalized patients, including hypertensive patients, in the meals of a hospital in Rio de Janeiro. They opted to determine the amount of sodium in all 'regular meals' served during the day, in a period of 7 days, through the dishes, the added salt, and the presence of processed food. The authors ${ }^{[2]}$ observed an excess of sodium of up to $90 \%$ above the recommendation of $2000 \mathrm{mg}$. An average of $3475 \mathrm{mg}$ of sodium was found, most of which in the main meals. The exceeding amount of sodium in the lunch and dinner meal were associated to the two salt packets that are sent on the trays which combined resulted in an increase of $800 \mathrm{mg}$ of sodium for both meals.

Considering that the lunch meals evaluated in this study were classified as part of a 'regular diet' (which requires no nutrient or consistency changes for dietary therapy purposes), their sodium content should be within the recommended guilines. Through the analysis of the salt added during the preparation of those meals, that limit has very likely been exceeded during this study.

The understanding of the risks associated to a high-sodium diet reinforces the necessity to develop interventions on the use of salt by the food service team, as well as by dinners (employees, patients and patient companions).

This study may contribute to the developing of interventions such as the control of the distribuition of salt from the storeroom and a more sensitive quantification of the amount of salt that should be added to a dish during preparations.

An internal reference list for considering the volume of food produced, for instance, could be developed to guide the amount of salt that should be used for preparing meats and side dishes.

Lastly, campaign material may be created for raising awereness on the importance of reducing the sodium intake, and therefore, the use of salt.

\section{CONCLUSION}

To understand the use patterns of salt as a seasoning inside of a food service is not only useful, but it is also necessary. The per capita amounts used to prepare regular lunch meals found in this study were compared to the intake recommendations, even though the amount of salt used in the preparation of a meal does not necessarily represents the salt ingested, and the plate waste percentage should be considered when estimating the final salt intake. 
An average of $2.34 \mathrm{~kg}$ of salt was used per day for preparing the lunch meal. Only the per capita amounts found for 14 days (45\%) were under the limit line established for lunch $(2.5 \mathrm{~g})$. The per capita amounts varied from $1.33 \mathrm{~g}$ to $5.87 \mathrm{~g}$ of salt per meal, and the average for the 31 days was $3.11 \mathrm{~g}$, which is $0.61 \mathrm{~g}(24 \%)$ above the limit line for lunch. The lowest and highest results could be associated to cooking techniques and ingredients.

The findings of this study are important since they provide support to the implantation of a control system for the distribution of salt from the storeroom to the kitchen, as well as data to elaborate guiding material to food handlers, and also campaign material that can be used to sensitize both the food service team and dinners (employees, patients and patient companions) about the use and consumption of salt.

\section{REFERENCES}

[1] WHO. World Health Organization. The Global Strategy on Diet, Physical Activity and Health (DPAS). 57th World Health Assembly (WHA). 2004. Accessed on March 03, 2019. Available at: who.int/dietphysicalactivity/strategy/eb11344/strategy _english_web.pdf.

[2] WHO. World Health Organization. Fact Sheet: Salt. Regional Office of South-East Asia. 2015. Accessed on June 02, 2019. Available at: who.int/iris/handle/10665/155294.

[3] FDA. U.S. Food and Drug Administration. Sodium in your Diet - Use the Nutrition Facts Label and Reduce Your Intake. United States, 2018. Accessed on June 01, 2019. Available at: fda.gov/media/84261/download.

[4] WHO. World Health Organization. Guideline: Sodium intake for adults and children. Geneva, 2012. Accessed on April 16, 2019. Available at: who.int/nutrition/publications/guidelines/sodium_int ake_printversion.pdf.

[5] WHO. World Health Organization. Fact sheets: salt reduction. 2020. Accessed on December 28, 2020. Available at: who.int/news-room/factsheets/detail/salt-reduction.
[6] WHO. World Health Organization. Reducing sodium intake to reduce blood pressure and risk of cardiovascular diseases in adults. e-Library of Evidence for Nutrition Actions (eLENA). 2019. Accessed on June 02, 2019. Available at: who.int/elena/titles/sodium_crd_adults/en/.

[7] WHO. World Health Organization. Diet, nutrition and the prevention of chronic diseases. Report of a Joint WHO/FAO Expert Consultation. Geneva; 2003. (WHO Technical report series, 916). Accessed on May 25, 2019. Available at: who.int/iris/bitstream/handle/10665/42665/WHO_ TRS_916.pdf.

[8] Nilson EA. The strides to reduce salt intake in Brazil: have we done enough? Cardiovasc Diagn Ther. 2015 Jun; 5(3):243-7. DOI: 10.3978/j.issn.22233652.2015.04.03.

[9] IBGE - Brazilian Institute of Geography and Statistics. Household Budget Survey 2008-2009. National Dietary Survey 2008-2009. Brasil. Rio de Janeiro, 2011. Accessed on Jan. 12, 2019. Available at: biblioteca.ibge.gov.br/visualizacao/livros/liv50063.pdf.

[10] Samo F, Claro RM, Levy RB, Bandoni DH, Ferreira SRG, Monteiro CA. Estimated sodium intake by the Brazilian population, 2002-2003. Rev Saúde Pública 2009;43(2). Accessed on June 01, 2019. Available at: scielo.br/pdf/rsp/v43n2/en_230.pdf.

[11] Brazil. Ministry of Health. Feeding Guide for the Brazilian Population: Promoting the Health Food. 1st ed. Brasília - DF, 2008. Accessed on May 15, 2019. Available at: bvsms.saude.gov.br/bvs/publicacoes/guia_alimentar_ populacao_brasileira_2008.pdf.

[12] Brazil. Vigitel Brazil 2016: Surveillance of Risk and Protective Factors for Chronic Diseases by Telephone Survey: Estimates of Sociodemographic Frequency and Distribution of Risk and Protective Factors for Chronic Diseases in the Capitals of the 26 Brazilian States and the Federal District in 2016. 2017. Accessed on December 29, 2020. Available at: portalsaude.saude.gov.br/images/pdf/2017/junho/07 /vigitel_2016_jun17.pdf.

[13] Oliveira MM, Malta DC, Santos MAS, Oliveira TP, Nilson EAF, Claro RM. Self-Reported High Salt Intake in Adults: Data from the National Health Survey, Brazil, 
2013. Epidemiol. Serv. Saúde. Brasília, 24(2): 2015. Accessed on June 01, 2019. Available at: scielo.br/pdf/ress/v24n2/en_2237-9622-ress-24-020249.pdf.

[14] Nilson EAF, Spaniol AM, Gonçalves VSS, Moura I, Silva SA, L'abbé M, Jaime PC. Sodium Reduction in Processed Foods in Brazil: Analysis of Food Categories and Voluntary Targets from 2011 to 2017. Nutrients. 2017 Jul 12;9(7):742. DOI: 10.3390/nu9070742.

[15] Borges SKS, Conde SR. Menu Sodium Quantity Evaluation of a Hospital Food and Nutrition Unit of a City of Caxias do Sul, RS. Revista UNINGÁ. v.21, n.2, pp.10-13. Jan/March 2015. Review ISSN online 21782571. Accessed on June 01, 2019. Available at: http://www.mastereditora.com.br/periodico/2015020 2_151448.pdf.

[16] Ottoni IC, Spinelli MGN. Sodium Offer in Meals in a School Food Service. Revista Univap. São José dos Campos-SP-Brasil, v. 20, n. 35, jul. 2014. DOI: 10.18066/revunivap.v20i35.176.

[17] Bertoncello TF, Cintra P. Analysis of the Amount of Sodium Chloride Used at Lunch of Food and Nutrition Unit in Dourados-MS. Interbio v.8 n.1 2014 ISSN 1981-3775. Accessed on April 10, 2019. Available at: unigran.br/interbio/paginas/ed_anterio res/vol8_num1/arquivos/artigo4.pdf.

[18] Klein C, Silva ABG. Avaliação do Consumo de Sódio em uma Unidade de Alimentação e Nutrição do Vale do Taquari. RevistaDestaquesAcadêmicos, vol. 4, n. 3, 2012 - ccbs/univates. Accessed on Feb. 02, 2019. Available at: univates.br/revistas/index.php/destaques/article/view $/ 151$.

[19] Capalonga R. Avaliação da Quantidade de Sal Oferecido no Almoço dos Funcionários de um Hospital Público de Porto Alegre. Universidade Federal do Rio Grande do Sul. Porto Alegre, 2007. Accessed on June 02, 2019. Available at: lume.ufrgs.br/bitstream/handle/10183/15765/000631 419.pdf.

[20] Mill JG et al. Estimation of salt intake in the Brazilian population: results from the 2013 National Health Survey. Rev. bras. epidemiol., Rio de Janeiro, v. 22, supl. 2, E190009.SUPL.2, 2019. Epub Oct 07, 2019. DOI: 10.1590/1980-549720190009.supl.2.
[21] Souza AM et al. The impact of the reduction of sodium content in processed foods in salt intake in Brazil. Cad. Saúde Pública, Rio de Janeiro, v. 32, n. 2, e00064615, 2016. Epub Feb 01, 2016. DOI: 10.1590/0102-311x00064615.

[22] Souza CS et al. Quantidade de Sódio em Refeições de Unidade Hospitalar no Rio de Janeiro. Internacional Journal of Cardiovascular Sciences. 2015;28(4):305-312. DOI: $10.5935 / 2359-4802.20150044$.

[23] Brazil.Vigitel Brazil 2019: surveillance of risk and protective factors for chronic diseases by telephone survey: estimates of frequency and sociodemographic distribution of risk and protective factors for chronic diseases in the capitals of the 26 Brazilian states and the Federal District in 2019. 2020. Accessed on December 31, 2020. Available at: bvsms.saude.gov.br/bvs/publicacoes/vigitel_brasil_20 19_vigilancia_fatores_risco.pdf. 